\title{
The diachronic evolution of future tense forms in French from the perspective of the re-grammaticalization theory
}

\author{
Cecilia-Mihaela Popescu* \\ Faculty of Letters, University of Craiova, Str. Alexandru Ioan Cuza 13, 200585 Craiova, Romania
}

\begin{abstract}
Article info
History:

Received January 26, 2018

Accepted February 13, 2018

Published April 27, 2018

Key words:

grammaticalization

re-grammaticalization

synthetic future

form in $-r a i$

periphrastic prospective

structures

probable epistemic
\end{abstract}

\begin{abstract}
Deriving from a comprehensive postdoctoral study, this article aims at presenting the evolution of future tense forms in French from the perspective of the regrammaticalization process, understood as re-organisation of the grammatical system of a language (v. Andersen, 2006; Lindschouw, 2011). In very general lines, this process may be described as follows: in time, canonical future forms, originally representing outcomes of previous 'grammaticalization' processes (i.e. transition from lexical to gramatical), eventually show a poly-functional morpho-syntactic and semantic behaviour, actualising more than one grammatical value. Such a situation will imply the selection of new constituents in the canonical future paradigm and will inevitably result in: (i) a competition between canonical forms and the newly created ones; (ii) a de-semantization and specialization of canonical forms in a certain informational segment, and (iii) the (total or partial) grammaticalization of the concurrent periphrastic forms. We shall thus see that the synthetic future form in French underwent a semantic-functional reduction in terms of actualisation of temporal [prospective], which is mostly due to the "intervention" and grammaticalization of the itive periphrasis aller + infinitive on the same conceptual area; in current spoken language, this periphrasis has become the most frequent form to express [future]. An even stronger reduction in the number of occurrences is seen in terms of purely modal uses, in spoken language, as native speakers again prefer a periphrastic structure, i.e. devoir ${ }_{\text {EPISTEMIC }}+$ infinitive.
\end{abstract}

\section{Introduction}

\subsection{Grammaticalization and re-grammaticalization}

Any linguistic system is constantly subject to change, and future (hereinafter: FUT) tense verb paradigms in Romance languages have also undergone various semantic and syntactic changes since they became established in the language, up to our days, sometimes even resulting in reorganisations of paradigm or in the creation of new types of oppositions at a system level.

This constant change affecting various forms that have already achieved grammatical status at a system level reopens the discussion on grammaticalization or, at least, on the traditional conceptualisation of this linguistic phenomenon (see Meillet, 1912, p. 130-148 or Lehmann, 1985, p. 303-318).

Seen in the classical canon, grammaticalization is the process of transition from lexical to gramatical, i.e., the process through with a semantically, lexically and syntactically independent item progressively loses its original meaning. Through its frequent use in certain less and less diverse syntactic patterns, this lexeme ends by becoming syntactically dependent. The absence of its own lexical meaning, its functionally dependent behaviour, corroborated with its formal erosion, all this range of irreversible (i.e. unidirectional) processes transform the original lexical item into a grammatical morpheme.

*Email address: cecilia99_ro@yahoo.com. 
Recent studies (see Andersen, 2001; 2006, p. 231-258 or Lindschouw, 2011, p. 57-63; 2013, p. $93-$ 95) have shown that the extremely generous landscape of grammaticalization includes a wide range of linguistic processes such as re-grammaticalization or re-analysis, which have been recently defined and disambiguated. For instance, Andersen (2006, p. 231-258) considers grammaticalization as including a range of other secondary processes, referred to as grammaticalizations <grammation(s)> and re-grammaticalizations $<$ régrammation $(\mathrm{s})>$. By grammaticalizations, the Danish scholar means "[...] un changement de contenu, au moyen duquel une catégorie qui n'a pas un contenu grammatical l'obtient"' (Lindschouw, 2011, p. 59), while re-grammaticalization is a re-organisation of a grammatical and functional content within a grammatical system or, as posited by Lindschouw (2011, p. 60), "une réorganisation à l'intérieur d'un paradigme clos [s.n.] qui présuppose un changement de la relation entre la forme et le contenu accompagné d'au moins une réduction paradigmatique".

The distinction between grammaticalization and re-grammaticalization is clearly shown in the FUT paradigm of contemporary French, where the analytical FUT form (aller chanter) is now undergoing full grammaticalization, while the synthetic form (chanterai) "est grammaticalisée depuis des temps immémoriaux" (Lindschouw, 2011, p. 57, note 4). However, according to the wider meaning recently assigned to the grammaticalization (now seen in extenso, as a re-organisation of grammatical systems), the synthetic FUT form in contemporary French is undergoing grammaticalization (or, more accurately, regrammaticalization), “[...] dans la mesure où son domaine d'emploi se restreint à l'intérieur du système du futur, alors que le futur analytique ouvre le sien” (Lindschouw, 2011, p. 57, note 4).

Besides, in his study on the evolution of the FUT system in French, Lindschouw (2011, p. 60-63) also synthesizes the possible phases a re-grammaticalization process can undergo, as follows:

- paradigmatic reduction or paradigmaticity (also see Lehmann, 1985), referring to a cancellation of oppositions between the constituents of a paradigm. This process results from the gradual reduction of the possibility to alternate the concerned items and results in their obligativity and syntagmatic specialisation;

- de-semantization of the semantic and functional content of the concerned paradigm;

- re-analysis, a comprehension strategy applied by the speaker, of an abstract cognitive nature, usually preceding the grammaticalization or re-grammaticalization process, and which primarily acts at the content level and then at a morphosyntactic structure level.

All these phases describing the re-grammaticalization or grammaticalization process in extenso may be synthesized as follows:

“[...] une forme A qui subira ultérieurement un processus de grammaticalisation, ou de régrammation dans notre cas, existe dans la langue pour traduire une valeur déterminée. Ensuite, une nouvelle forme $\mathrm{B}$, concurrente de $\mathrm{A}$, entre dans la langue, ce qui crée une ambiguïté référentielle [s.n.] entre la forme A et B. Enfin, la forme A se perd (ou souvent se (ré)grammaticalise), et seule la forme B est capable d'exprimer la valeur réservée autrefois à la forme A" (Lindschouw, 2011, p. 63).

\subsection{The re-grammaticalization of the synthetic future in French - introductory elements}

In the following, we shall attempt at following the re-grammaticalization process of the synthetic FUT in French. As shown above, this process has taken place (or is still taking place) in relation with other members of the FUT paradigm, mostly periphrastic, analytic structures, more or less grammaticalized. In very general lines, it may be described as follows: synthetic FUT forms originally are outcomes of previous grammaticalization processes (transition from lexical to grammatical) and, to a lesser extent, of re-grammaticalization processes, as long as pre-Romance forms (i.e. forms deriving from the structure CANTARE HABEO) had already acquired a certain functional status within the original grammatical system (Latin, in our case). In time, these grammatical items end having a polyfunctional morphosyntactic 
and semantic behaviour, actualising several grammatical values, which will result in the selection of new members in the FUT paradigm of French. This will inevitably result in:

(i) a competition between the canonical FUT form and newly created forms;

(ii) de-semantization and specialization of the canonical form for a certain informative segment, and

(iii) (total or partial) grammaticalization of periphrastic forms.

Even if they do not approach the evolution of Romance FUT forms from the extended perspective of grammaticalization, various scientific studies focusing on typology (see Fleischman, 1982; Bybee et al., 1994; Barcelo, 2007, p. 47-62) suggest a cyclic evolution generally followed by the constituents of the concerned paradigm, which actually translates the transition from TEMPORALITY to MODALITY. Actually, a certain pattern of evolution of verbal morphemes actualizing [posteriority to $T_{0}$ ], can be configured, as synthesized in the definition below:

“[...] o construcție, la origine modală, asociază la un moment dat mai mult de o valență temporală - [posterioritatea față de $\left.t_{0}\right]$, care, ulterior, devine trăsătura sa definitorie. După ce începe să fie utilizată exclusiv cu valoare de viitor, o astfel de construcție începe să dezvolte anumite semnificații modale, care, la rîndul lor, pot să se impună în detrimentul valorii temporale” (Corcheș \& Roman, 2011, p. 313).

\section{French synthetic future and its competition with various periphrastic structures}

In this section, we shall see-closely following Lindschouw's study (2011, p. 51-63)-that the French synthetic FUT lost many of the specific meanings of prospective reference, which was mostly due to the "intervention" and grammaticalization of the itive periphrasis aller + infinitive on the same conceptual area.

However, before presenting this evolution, two general comments are needed:

(i) The grammaticalization of structures initially created with movement verbs, such as: aller, venir, etc. is not specific to French, but is also seen in other areas of Romania, in Spanish, Portuguese, Catalan and, to some extent, in Italian ${ }^{1}$. Studies of linguistic typologies (see, inter alia, Bybee et al., 1994) have analysed in detail the evolution of these verbal lexemes with the original meaning [+movement] towards temporal morphemes (i.e. auxiliary verbs), through their association with an infinitive or a gerund or even, but more seldom, a past participle.

(ii) Due to the semantic and functional reduction undergone by the synthetic FUT form in terms of actualisation of temporal [prospective], several linguists (see Harris, 1978; Bybee et al., 1994; Fleischman, 1982) came to consider that, in the current state of French, this verbal morpheme prevalently operates in the modal area and less in the temporal one. However, on the one hand, the synchronic analysis we have developed in various papers (see Popescu, 2013, 2016) on the values of FUT in contemporary French and, on the other hand, the investigation proposed by Wales (2007, p. 1-14) on the dynamics and frequency of the various types of occurrence of this paradigm in spoken language show that: pursuant to the re-grammaticalization process, the canonical FUT form in French does not disappear completely; on the contrary, it keeps most of its uses that are still anchored in the field of expression of [temporality]. Moreover, in the oral code of this linguistic system, the synthetic FUT is very seldom used with modal values, which are actually either temporal-modal, or attenuative and, very rarely, epistemic, where FUT is frequently replaced by the modal periphrasis

\footnotetext{
${ }^{1}$ In French, Spanish and Portuguese, synthetic FUT with a purely temporal value is challenged by certain periphrastic structures formed with the auxiliary "go" in present tense, followed by the infinitive of the lexical verb: (Fr.) aller + infinitive; (Sp.) ir $+a+$ infinitive; (Port.) ir + infinitive. In Italian, an equivalent structure to the above mentioned ones is andare $a+$ infinitive, as well as the progressive, non-itive form, stare per + infinitive.
} 
devoir $_{\text {Eтіsтемic }}+$ infinitive, or by the present tense accompanied by the modalizing adverbs probablement, sans doute, peut-être. In conclusion, what we think should be retained for our approach is that, in French, the canonical FUT form keeps operating frequently in temporal occurrences, that it has lost-admittedly - a large number of them (which is mostly visible in the oral code) due to the competition with the periphrastic structure aller + infinitive, which has become the primary way to express [future] in contemporary spoken language. However, the most significant loss experienced by the synthetic FUT form should be signalled in terms of modal uses, where, in spoken language as well, native speakers prefer another periphrastic structure, i.e., devoir $r_{\text {ерізтеміс }}+$ infinitive.

In the following, we shall briefly see how this diachronic change took place, which is, in our opinion, a process of re-grammaticalization (not yet completed), since it entails various semantic and functional changes and, thus, a re-organisation of the FUT paradigm in this language.

\subsection{The -raiform $v$ s the itive periphrasis aller + infinitive}

The predecessor of the -rai form of modern French is attested (as an already merged form) in the very first written text in this language, i.e., Les Serments de Strasbourg (year 842 A.D.). At that time, as a single form of the FUT paradigm, the concerned verbal morpheme, described by Moignet (1959, p. 289) as "un futur comportant une dose d'hypothèse, si petite qu'on la fasse [...]", frequently appears with temporal value [see infra, (1a,b) or (6)], as well as with various temporal and modal nuances, as a substitute of the -roie form in expressing an attenuated statement (2), and very rarely with a modal epistemic value [such cases are found in interrogative and exclamative structures that contribute to triggering a strong modal nuance of the entire statement-e.g., an expression of a discussion on a [probability], related to [present-future]see infra, example (3)]:

(1) a. Ilz mangeront maint bon morseau // Les enffans, quant je seray vieuls (Villon, Le lais Villon et lespoèmes variés, 23, 2160, apud Lindschouw, 2011, p. 74) [synthetic FUT with temporal value, detached from the [present] of $\left.\mathrm{Sit}_{0}\right]$.

b. A present je ne parleray principalment que du tiers mirouer de humaine creature, et de la belle ymaige de la benoite Trinité (Gerson, Sermon pour la fête de la sainte trinité, 155, 2057, year 1402, apud Lindschouw, 2011, p. 74) [synthetic FUT with temporal value, related to $\mathrm{Sit}_{0}$ ].

(2) C'iert granz damages, s'il est deserites (Cor. Lo., 1410, apud Moignet, 1976, p. 289) [synthetic FUT with attenuative value in the apodosis of a conditional system].

«Ce serait un grand domage, si...».

(3) a. Ferai le pendre ou se l'ardrai ? (Thèbes 8208, apud Moignet, 1976, p. 289)

b. Menderai li? -Tes, fous, ne feire... (Eneas 9073, apud Moignet, 1976, p. 289).

c. Deux! Que ferai? Por coi viv tant? (Erec 4617, apud Moignet, 1976, p. 289) [synthetic FUT in interrogative structures, with a dubitative value, expressing <probable potential> with reference to [present-future]].

In other words, in the Old and Middle French, the predecessor of the -rai form expresses [prospective] both with reference to $T_{0}$ (hence, operating deictically), and independently from this enunciative parameter. We should state that, in the first case, the distance between the location of the event situated in the [future] and the moment of the communication situation is not, for the studied age, a relevant feature in organising the means of expressing [prospective]:

"Il est fort probable que pour un locuteur du moyen français, le futur synthétique exprimait une postériorité par rapport au moment de l'énonciation, peu importe la distance temporelle entre le moment de l'énonciation et le moment de l'événement exprimé par le verbe" (Lindschouw, 2011, p. 74). 
The periphrastic FUT form appears in texts as of the $14^{\text {th }}$ century, hence containing a verb of movement and the infinitive of a lexical verb. The contexts favouring the grammaticalization of this itive periphrasis as a temporal morpheme are thought to be the ones where the purpose of movement was actualised, thereafter re-analysed by the speakers in favour of a temporal interpretation. It should be said that aller + infinitive is not the only periphrasis appearing in the field of expression of [prospective] in Old French. Actually, unlike the modern language, Old French and especially Middle French have an entire range of periphrastic structure for expressing [prospective], strongly marked from an aspectual point of view and which, inserted in various combinations of phrase structures (both paratactic and hypotactic), exclude the process from contemporaneity and provide it with a slight modal, virtual, frequently retrospective nuance.

For instance, devoir, cuidier or vouloir, followed by the infinitive of the lexical verb, form periphrases (frequently found in Middle Ages texts), cumulatively rendering a prospective event, frequently marked by the following semes: [+imminence] [+failure].

(4) Et quant ilz'en furent allez, le roy cuydoit dormir, mais il nepouvoit, si veilla toute la nuyt (Jehan, 22, 1, 26, apud Martin, 1971, p. 174)

«Et quand ils s'en furent allés, le roi aurait voulu s'endormir, mais il n'aurait pas pu si (...)».

(5) Vespres aproche, li solaus dut cliner (Ami et Amile, 579, apud Ménard, 1976, p. 133).

«Le soir vint, le soleil allait se coucher».

(6) Navrés estoit d'un roit espieu burni // Chaoir voloit ${ }^{2}$ del destrier arabi, // Quant.I. borgois en bras le saisi (Raoul de Cambrai, 3528, apud Buridant, 2000, p. 335).

«Blessé par une lance rigide bien fourbie, il allait tomber du cheval arabe quand un bourgeois le prit entre ses bras».

The same interpretation is assigned to much more expressive contexts with the periphrasis including a present participle (the - ant form) - indicating a process about to be undertaken — and the verb ester (frequently conjugated in the future tense) [cf. Romanian - see Popescu, 2017]:

(7) Ja Loeys ne lor sera aidans (Raoul de Cambrai, 3929, apud Ménard, 1976, p. 171). «Louis ne leur viendra pas en aide».

(8) Ultre cest jurn ne serum plus vivant (Roland, 1520, apud Ménard, 1976, p. 171) «Au-delà de ce jour nous ne serons plus en vie».

However, going back to aller + infinitive, it should be said that it begins to be frequently found in texts as of the $15^{\text {th }}$ century. Like the synthetic FUT form, the analytical one is found both with temporal values, related to $\mathrm{Sit}_{0}$ [see examples (9) and (10)], and with temporal and modal, frequently deontic, values.

(9) Lors embrasse cellui qui lui rapporte // Et va passer trois fois devant la porte // Pour veoir la preuve, [...] (Chartier, Le débat des deux fortunes d'amour, 163, apud Lindschouw, 2011, p. 75) [periphrastic FUT used in a 1412 text, with a generic temporal value, not related to $\left.\mathrm{Sit}_{0}\right]$.

(10) SATHAN : Alons, Belzebuth, mauldit dyable, // Et portarons l'arme en enfer,

BELZEBUth : Mes griffes sont toutes de fer // De quoi je la vays accrocher (Anonyme, La passion d'Auvergne, 112, apud Lindschouw, 2011, p. 75) [periphrastic FUT used in a 1477 text, with a temporal value depending on the situational context described by $\left.\mathrm{Sit}_{0}\right]$.

However, in terms of distribution of the occurrences of the two paradigms in the $15^{\text {th }}$ century, the situation is as follows (apud Lindschouw, 2011, p. 73): in more than half of the occurrences (about 89,5\%), the canonical form is used with a purely temporal value, in $7,5 \%$ of the cases it appears with a temporal modal value, and only $2 \%$ of all the uses are purely modal. The analytic form aller + infinitive is instead prevalently

\footnotetext{
${ }^{2}$ This use disappeared in literary French as of the $16^{\text {th }}$ century. However, vouloir + infinitive appears in various varieties of French, as equivalent to an indicative FUT (see Ménard, 1976, p. 133).
} 
$(99,5 \%)$ found in temporal occurrences, with a minimal number $(0,5 \%)$ being affected by a slight modal nuance. What is interesting, related to the fundamental value held by this structure in contemporary language, is that, among temporal occurrences, aller + infinitive frequently appears not directly related to $\mathrm{Sit}_{0}$ [as supra, example (10)], but with a generic temporal value, as previously seen in (9). This meansin Lindschouw's statistics (2011, p. 72) - a ratio of 1 (i.e., 2\%) to 5 (i.e., 10,5\%). However, it should be underlined that, among all temporal occurrences of the concerned periphrasis in $15^{\text {th }}$ century texts, the highest number - which is again surprising! - is found in historical contexts, where it reaches a percentage of $82,5 \%$ [ see example (11)] of the total of $99,5 \%$ :

(11) Quant vint le dimanche à matin et jour qu'il trespassa, fist appeler devant lui tous ses barons, prelay, son conseil et chancelier; adonc va parler devant eulz moult piteuses paroles, si que tous les contreigni à lermes (Ch. de Pizan, Le livre des fais et bonnes meurs du sage roy Charles V, 185, 2255, year 1404, apud Lindschouw, 2011, p. 75).

(12) Sur ces propos, feirent leur accord, et, en regardant le lieu le plus propre pour faire ceste belle cuvre, elle vat dire quelle n'en sçavoit poinct de meilleure ne plus loing de tout soupson, que une petite maison qui estoit dedans le parc, où il y avoit chambre et lict tout à propos. Le gentil homme, qui n'eust trouvé nul lieu mauvais, se contenta de cestuy-là (M. de Navarre, L'Heptaméron, 1550, apud Bres \& Labeau, 2013, p. 296).

This type of uses of the itive periphrasis is worth of an extended discussion, as long as they, apparently, reappeared (see Lindschouw, 2011, p. 76; Bres \& Labeau, 2013) in contemporary French as well [see infra, example (13)]:

(13) C'est le producteur Rob Fusari qui va trouver le nom de Lady Gaga, en sinspirant de Radio Gaga, une chanson du groupe Queen. Dans cette logique, la créature Lady Gaga claque la porte du rock pour ouvrir celle de la dance musique, dans le sillage de Madonna. Avant de réussir à vendre 14 millions d'albums et 35 millions de singles en pleine crise du disque, Lady Gaga a puisé son inspiration dans le monde de la nuit new-yorkaise en se produisant avec DJ Lady Starlight qui va l'orienter vers l'exubérance esthétique. Dès lors, Lady Gaga va pousser la culture gay à son paroxysme ... (Le Monde, May 16-17, 2010, apud Bres \& Labeau, 2013, p. 296).

Sporadically attested from the $12^{\text {th }}$ century (the first uses are seen in Orson de Beauvais and, subsequently, in the $13^{\text {th }}$ century, in Le Roman de la Rose), such occurrences are thought to originate in Old Gascon (see Lindschouw, 2011, p. 76), even though similar structures have been seen in Old Occitan, in Old Castilian or Old Portuguese (see Bres \& Labeau, 2013, p. 299), while the equivalent structure in contemporary Catalan, vaig cantar, has been grammaticalized as a neutral form of actualisation of [past]. This type of historical narrative use of the periphrasis aller + infinitive will decrease as of the $16^{\text {th }}$ century and will disappear in the $18^{\text {th }}$ century, to reappear-as shown by certain French linguists (such as Bres \& Labeau, 2013, p. 295-322) — in contemporary French. Bres \& Labeau (2013), describing the general operating mechanisms of the discussed periphrasis in narrative contexts as follows:

"[...] the aller auxiliary in the present signifies a prospective orientation towards the initial boundary of the event expressed by the following infinitive that is ASPECTUALLY understood as having reached its final boundary. At a TEXTUAL level, that process introduces a new reference point in the diegesis and contributes to the progression of the narration. At a CONTEXTUAL level, i.e. at the level of linguistic context, it refers to an event located before the moment of narration-that is to say in the past. It works ANAPHORICALLY and not deictically: the prospective movement originates in the situation that precedes it rather than in the moment of speech" (Bres \& Labeau, 2013, p. 297), 
emphasize that there is a major difference between old and contemporary occurrences. Indeed, in both periods, the concerned periphrasis with a preterite value can be replaced by a form of present tense-which cannot happen when it has a FUT value - and never accepts the insertion of the modalizing adverb probablement "probably", but it is compatible with it when expressing [prospective], both generic or related to $\mathrm{Sit}_{0}$. The difference between the Middle French use and the current discursive pattern refers to the possibility of dependence and/or contextual coordination related to a present tense (or even related to a different form of FUT), which is only valid for the contemporary state of operation. The consideration of this distinctive factor makes Bres \& Labeau (2013) consider that, actually, the old structure disappeared as of the $18^{\text {th }}$ century, and contemporary equivalent occurrences are new discursive structures (timidly re-arising as of the $17^{\text {th }}$ century), determined by the prospective attributes of this itive periphrasis. Unlike Middle Ages use, frequent in narrative or written academic texts, modern use is very seldom seen in writing, especially in narrative fiction, as well as in interactive oral narration. However, modern occurrences are more numerous in the media or scientific discourse (see Bres \& Labeau, 2013, p. 319). The appearance of this new use of the prospective structure aller + infinitive in contemporary French can be explained as follows:

"En effet, sur la base de son interprétation future, $v a+$ INF. permet l'organisation de la narration, annonçant les faits suivants par un procès hyperonymique. La périphrase s'approche ainsi d'une valeur narrative en projetant le temps des événements sur celui de la narration. Avec la disparition de tous les marqueurs déictiques, les périphrases en aller cessent d'agir comme hypéronymes : elles apparaissent sur la même ligne temporelle que les situations voisines et s'interprètent comme actualisant des procès complètement réalisés » (Bres \& Labeau, 2013, p. 321).

Without going into further detail, we should underline, conclusively for our approach, that this type of narrative use of the itive structure aller + infinitive (seen globally-from the Middle French to our days) again proves that:

(i) in such (narrative) occurrences, the involved prospective verbal morphemes (be it the canonical FUT form or even certain periphrases) are not completely synonymous with the past forms they can be replaced with, but they work as markers (of various grades) of illocutionary force. This is perhaps the reason for which Wilmet (1970, p. 188) considers that this use of actualisation of future in the past is "impure";

(ii) seen from the perspective of the classical and extended theory of grammaticalization, the diachronic itinerary of aller + infinitive shows that (1) the same structure can be grammaticalized differently and even completely opposite from one linguistic to another (cf. Catalan), respectively that (2) the same already grammaticalized item may develop similar discursive meanings in various periods of its "life", given the existence of a fundamental/essential semic/componential feature in its sememe.

Going back to the general discussion on the re-grammaticalization process of canonical FUT, we remind that the disappearance of the narrative occurrences of aller + infinitive in French primarily coincides with the specialisation of canonical FUT in the actualisation of [prospective] detached from the allocentric universe, i.e. as a prospective temporal morpheme focusing rather on the action/event expressed by the verb (actually, the moment of the event) than the communication situation. Conversely, it should be emphasized that, by losing its high number of narrative occurrences, the analytical FUT form has reinforced:

“[...] son statut comme forme temporelle 'authentique', de par sa capacité à marquer un rapport avec le moment de l'énonciation, cette valeur étant passée de 2,0\% au $15^{\mathrm{e}}$ siècle à $90,5 \%$ au $18^{\mathrm{e}}$ siècle. Ce contenu s'observe dans un vaste éventail de genres textuels (c.-à-d. textes argumentatifs et littéraires, discours direct et pièces de théâtre en vers et en prose), ce qui peut être interprété comme un témoignage du fait qu'il appartient à toute la réalité langagière" (Lindschouw, 2011, p. 83). 
In this context, it should be reiterated that this discursive variety and this high number of occurrences of the periphrastic structure mostly appear in the written code, where this verbal morpheme is mostly associated with the actualisation of a future generic action, i.e. not related to $\mathrm{Sit}_{0}$. All this descriptive landscape actually shows that the analytical FUT form has extended its scope of use: even though the original value, i.e. of expressing a prospective action related to $\mathrm{Sit}_{0}$ (hence, the actualisation of an immediate/close FUT) has decreased in terms of occurrences, it is mostly maintained in written language. Besides this value, aller + infinitive has extended, especially in the oral code, in the area of operation once exclusively reserved to the synthetic form, i.e. the actualisation of a generic FUT, not related to $\mathrm{Sit}_{0}$.

“Toutefois, il serait faux d'affirmer que ce tiroir verbal [le futur] a subi un processus de désemantisation, puisque, en dépit des réductions qu'il a connues, il constitue toujours un système temporel bipartite quoique dans une moindre mesure quà l'origine. Il n'a pas subi un processus d'obligatorification' ou de spécialisation de son emploi, et par là une réduction paradigmatique" (Lindschouw, 2011, p. 89).

However, it would be premature to say that the canonical FUT form in French has undergone and completed the re-grammaticalization process, since the two verbal paradigms are still alternative in certain contexts (cf. infra, examples (14a) and (14b); for more details, see Costăchescu, 2013, p. 167-172):
a. Jean se mariera l'an prochain.
b. Jean va se marier l'an prochain (apud Helland, 1995, p. 5).

\subsection{The -rai form vs the modal periphrasis devoir + infinitive}

As for modal uses of the canonical FUT form-a value we have seen has not developed from the temporal use, but has coexisted with it from the old age of French - in contemporary language, such occurrences are low compared to other Romance systems (e.g. Italian or Romanian), but high compared to other phases of evolution. For this statement to be valid, the types of modal uses of the FUT have to be differentiated into epistemic uses and other types of uses, i.e. attenuative and deontic. In this methodological framework, it should be said that, in the Old and the Middle French, the number of attenuative and jussive occurrences is high indeed, unlike the number of epistemic uses which are rare and reserved-as seen above-only for interrogative and exclamatory phrases where the [dubitative probability] value is triggered not by the FUT verbal morpheme, but by the entire enunciative structure. However, it is seen that, at these times, the FUT in such epistemic phrases is combined with a much wider and varied range of verbs compared to contemporary French (where it appears restricted to être and avoir) and has a syntactic and semantic behaviour similar to the present of conditional [cf. (15a) and (15b)]:

a. - Regardez quel fut vostre entraige

- Auront prins fin tous mes plaisirs? (E. Picot, Recueil général des sotties, apud Squartini, 2004, p. 88).

b. Seroient toutes mes marchandises / Par ung seul cas ainsi surprises? (E. Picot, Recueil général des sotties, apud Squartini, 2004, p. 88).

Thus, only seen as a whole, all these occurrences of the FUT (generally referred to as "modal": deontic, attenuative and epistemic) may be considered prevalent in contemporary language and this mostly refers to written language.

In spoken language, however, the attenuative FUT is frequently replaced by the conditional, and the epistemic FUT either appears in a complementary distribution (depending on the type of phrase) with the -roie form, or is replaced by the modal periphrasis devoir $r_{\text {еріsтеміс }}+$ infinitive, representing the favourite expression form (see Wales, 2007; Gobert \& Maisier, 1995, p. 1003-1014) for the actualisation of [epistemic probability] related to [present-future], as well as [past]. 
This latter periphrasis, devoir + infinitive — attested with an epistemic value quite early, around 1100-, is not inherited from Latin, as DEBERE only had the meaning of "obligation" or "necessity". The epistemic meaning [see example (17)] is posterior to such phases and is also experienced by the equivalent Italian form.

(16) Li soens orgoilz le devreit bien confondre (La chanson de Roland, versul 389, apud TLF, quoted by Rossari et al., 2007, p. 11).

(17) Mais ildoit moltcels anuier // Quiperdue l'ont folement (Vair Parlefroi, 1254, apud Ménard, 1976, p. 134).

«Mais ceux qui l'ont sottement laissée partir doivent sans doute être fort ennuyés».

Scientific literature includes two positions regarding the grammaticalization of the successors of DEBERE as marks of epistemic modality: either the epistemic value derives from the deontic, "obligation" one, as supported by Bybee et al. (1994), or we are dealing with a transition from alethic to epistemic, as suggested by Kronning (1990, p. 301-312) (also see Bourova, 2005, p. 310-312). Anyway, the number of modal occurrences with the value of "obligation" or "necessity" is strictly superior to the epistemic uses in the Old and the Middle French, compared to what happens in the actuality, where-as seen by Rossari et al. (2007, p. 11) - the proportion is inverse. This statistics firstly shows that the epistemic reading triggered by this periphrastic structure is certainly subsequent to the one of "obligation" or "necessity".

\section{Some conclusions}

As for the evolution of the canonical FUT form in French, it is certain that it is undergoing a full regrammaticalization process, since:

- in terms of temporal occurrences, the competition with the itive (grammaticalized) periphrasis aller + infinitive results not only in a decreased frequency of use, especially in spoken language, but also in a reconfiguration of the two paradigms in terms of reference to $\mathrm{Sit}_{0}$. The synthetic form still actualises generic [prospective], but also loses in number of uses, while the analytical structure is gaining field in marking a FUT with no reference to $\mathrm{Sit}_{0}$, and without using its essential value of marking an immediate/close [future] either. An immediate consequence of the attempt to detach from the reference to the situation of communication and generic marking of the prospective temporal reference is the possible use (mainly in the oral code) of this periphrastic structure in epistemic-evidential contexts, such as:

(18) On a sonné à la porte. Ça va encore être les témoins de Jéhovah.

- in terms of epistemic modal occurrences, the synthetic FUT no longer appears in dubitative and interrogative structures as in the Middle French and only combines with être and avoir and the assertive type of phrase, actually resulting in almost fixed structures for marking [epistemic probability]. In this cognitive area, the synthetic FUT is strongly challenged by the modal periphrasis (not fully grammaticalized yet) devoir еріSтеміс + infinitive and by conditional forms. The complementary distribution with this latter verbal morpheme shows that French operates a disambiguation between two cognitive-enunciative areas, i.e. [dubitative] and [inferential]. On the other hand, the functional competition-stronger and stronger, especially in the oral code-with the modal periphrasis shows not only a decrease in the number of such occurrences of the synthetic FUT, but even its complete regrammaticalization in this area of expression: the synthetic FUT becomes per se an inductive inference marker, which no longer marks the (logical, contextual, argumentative and enunciative) relation with the referential complex $R$ (see Popescu, 2016), but seems to include it intrinsically (in other words, it has assimilated it, it has grammaticalized it). All this assumption repositioned in the perspective of [evidentiality] makes us reconsider, as shown by Rossari et al. (2007), the opposition existing in 
contemporary French between the synthetic FUT and the modalized periphrasis based on the dichotomy [ \pm indication of the source of information], as synthetic FUT is not unmarked from this point of view. Moreover, at a temporal level, if the relation of inference may be configured in terms of [past] -

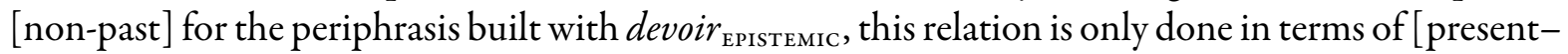
future] - (rarely) [future] for the synthetic FUT form.

- the restriction of the global area of use of the synthetic FUT form is also seen in other types of occurrences (temporal-modal-jussive, deontic, etc.—or attenuative ones), which are also found in regression compared to other phases of evolution of this linguistic system (see Popescu, 2013).

\section{Bibliography}

Andersen, H. (ed.) (2001). Actualization: Linguistic Change in Progress, John Benjamins, Amsterdam / Philadelphia, Crossref. Andersen, H. (2006). Grammation, regrammation and degrammation: tense loss in Russian, in "Diachronica", vol. 23, iss. 2, p. 231-258, Crossref.

Barcelo, G.J. (2007). Le(s) futur(s) dans les langues romanes: évolution linéaire ou cyclique?, in "Cahiers Chronos" [Labeau, E. (ed.). "Sémantique et diachronie du système verbal français"], vol. 16, p. 47-62.

Bourova, V. (2005). À la recherche du 'conditionnel latin': les constructions Infinitif + forme de HABERE examinées à partir d'un corpus électronique, in Kabatek, J., Pusch, C. D., Raible, W. (eds), Romanistische Korpuslinguistik II: Korpora und diachrone Sprachwissenschaft / Romance corpus linguistics II: corpora and diachronic linguistics, Gunter Narr, Tübingen, p. 303-315.

Bres, J. \& Labeau, E. (2013). The narrative construction va + INFINITIVE in Contemporary French, in "Diachronica”, vol. 30, iss. 3, p. 295-322, Crossref.

Buridant, C. (2000). Grammaire nouvelle de l'ancien français, SEDES, Paris.

Bybee, J., Perkins, W. \& Pagliuca, J.-R. (1994). The Evolution of Grammar. Tense, Aspect and Modality in the Languages of the World, The University of Chicago Press, Chicago / Londra.

Corcheș, C. \& Roman, D. (2011). Observations on the regenerative capacity of grammatical structures: the Romanian present presumptive, in Ciulei, T., Sandache, C. \& Sandu, A. (eds), Logos, Universalitate, Mentalitate, Educație, Noutate. Secțiunea Filosofie și Științe Umaniste / Logos Universality Mentality Education Novelty. Section: Philosophy and Humanistic Sciences, vol. 1, Editura Lumen, Iași, p. 309-324.

Costăchescu, A. (2013). La pragmatique linguistique : théories, débats, exemples, Lincom Europa, Berlin.

Fleischman, S. (1982). The future in thought and language. Diachronic Evidence from Romance, Cambridge University Press, Cambridge.

Gobert, D. L. \& Maisier, V. (1995). Valeurs modales du futur et du conditionnel et leurs emplois en français contemporain, in "The French Review", vol. 68, iss. 6, p. 1003-1014.

Harris, M. (1978). The Evolution of French Syntax. A comparative approach, Longman Group Ltd, Londra / New York.

Helland, H.P. (1995). Futur simple et futur périphrastique: du sens aux emplois, in "Revue Romane", vol. 30, iss. 1, p. 3-26, [online].

Hopper, P.J. \& Closs-Traugott, E. (2003). Grammaticalization, Cambridge University Press, Cambridge.

Kronning, H. (1990). Modalité et diachronie: du déontique à l'épistémique. L'évolution sémantique de «debere/devoir», in "Actes du XIe Congrès des Romanistes Scandinaves", Trondheim, p. 301-312.

Lehmann, Ch. (1985). Grammaticalization: Synchronic Variation and Diachronic Change, in "Lingua e Stile", vol. 20, iss. 3, p. 303-318.

Lindschouw, J. (2011). L'évolution du système du futur du moyen français au français moderne: la réorganisation comme un cas de régrammation, in "Revue de Linguistique Romane", vol. 75, iss. 297-298, p. 51-98.

Lindschouw, J. (2013). Passé simple et passé composé dans l'histoire du français. Changement paradigmatique, réorganisation et régrammation, in "Revue de Linguistique Romane", vol. 77, iss. 305-306, p. 87-120.

Martin, R. (1971). Temps et aspect. Essai sur l'emploi des temps narratifs en moyen français, Éditions Klincksieck, Paris.

Ménard, Ph. (1976). Manuel du français du Moyen Agge. 1. Syntaxe de l'ancien français, Editions Bière, Bordeaux.

Meillet, A. (1912). L'évolution des formes grammaticales, in Linguistique historique et linguistique générale, Honoré Champion, Paris, p. 130-148.

Moignet, G. (1959). Essai sur le mode subjonctifen latin postclassique et en ancien français, 2 vol., Presses Universitaires de France, Paris.

Moignet, G. (1976). Grammaire de l'ancien français. Morphologie-Syntaxe, Librairie Klincksieck, Paris.

Popescu, C.M. (2013). Viitorul și condiționalul în limbile romanice. Abordare morfosintactică și categorizare semantică din perspectivă diacronică, Editura Universitaria, Craiova.

Popescu, C.M. (2016). Manifestations discursives du «futur épistemique » en français contemporain, in Guță, A., Popescu, M. \& Teodorescu, C. (coord.), Actes du colloque international « 50 ans de français a l'Universite de Craiova (1966-2026) », 
Craiova, du 19 au 20 mai 2016, vol. 1: Perspectives linguistiques et lexicographiques, Editura Universitaria, Craiova, p. 201218.

Popescu, C.M. (2017). Evoluția sistemului formelor prospective din limba română, un exemplu de regramatizare, in Stanciu Istrate, M. \& Răuțu, D. (eds), Lucrările celui de-al VI-lea Simpozion Internaţional de lingvistică. Omagiu domnului academician Marius Sala, la aniversare, Editura Univers Enciclopedic Gold, București, p. 624-635.

Rossari, C., Cojocariu, C., Ricci, C. \& Spiridon, A. (2007). Devoir et l'évidentialité en français et en roumain, in "Discours. Revue de linguistique, psycholinguistique et informatique”, 1, Presses Universitaires de Caen, Caen, p. 2-15, [online].

Squartini, M. (2004). La relazione semantica tra futuro e condizionale nelle lingue romanze, in "Revue Romane", vol. 39, iss. 1, p. 68-96, Crossref.

Wales, M.L. (2007). Modal Functions of Future Tenses in French, in Mushin, I. \& Laughren, M. (eds), Selected Papers from the 2006 Annual meeting of the Australian Linguistic Society, University of Queensland, Brisbane, p. 1-14, [online].

Wilmet, M. (1970). Le systeme de l'indicatif en Moyen Français, Droz, Geneva. 